racic surgical training centers during the twelve months. Patient contact will be determined by the sponsoring surgeon and will conform to the regulations and licensing requirements of the state, province, or country in which he/she is studying.

A candidate should have completed his/her formal training in general surgery and in thoracic and cardiovascular surgery, but he/she should not have reached a senior position. Candidates must be sufficiently proficient in English to realize the full benefits of the fellowship. Candidate should not have had extensive clinical training in North America prior to making application, and should be planning to return to their native country following the completion of their fellowship. "Extensive" clinical training shall mean any period of clinical training which exceeds a total of six months in duration.

The online application submission site will be available beginning in March 2006 at www.aats.org. All applications must be submitted electronically via the online application submission site no later than July 1 . The selected candidate will be notified by November 1 .

\section{Resident Traveling Fellowship, 2006-2007}

$\mathrm{T}$ The American Association for Thoracic Surgery announces the Resident Traveling Fellowship, a program established to broaden the educational experience of residents in their final year of an approved cardiothoracic surgical training program by providing an opportunity to spend up to two weeks at one or more institutions other than their home institution.

A grant of $\$ 5,000$ will be provided to successful applicants to underwrite their travel and living expenses incurred during up to two weeks of training at one or more host institutions. The funds are also intended to provide for roundtrip travel and four nights' accommodations at the annual meeting of the Association scheduled for May 5-9, 2007 in Washington DC. The fellowship must be completed prior to March 31, 2007.

Applicants must have the approval of their home and prospective host institutions. Candidates must submit an online AATS application and include a one-page outline of what they hope to accomplish during their training. Additionally, award recipients must agree to submit a summary report to the membership of the association within thirty days after the completion of their training.

The candidate must be a North American resident in his or her final year (during 2006-07) of an approved cardiothoracic surgical training program.

Applications must be completed and submitted online at www. aats.org by July 1 . The selected candidates will be notified by September 30 to accommodate travel between October 1, 2006 and March 31, 2007.

\section{Second Dwight Harken Research Scholarship, 2007-2009}

$\mathrm{T}$ The American Association for Thoracic Surgery announces the Second Dwight Harken Research Scholarship to provide an opportunity for research, training and experience for North American surgeons committed to pursuing an academic career in cardiothoracic surgery. The scholarship will be funded by the Association and administered by the Graham Education and Research Foundation.

The research program must be undertaken within the first three years after completion of an approved cardiothoracic residency.
Applications for the scholarship may be submitted during the candidate's final year of cardiothoracic residency or during his or her first two years in an academic position. The duration of the scholarship is to be two years.

The yearly stipend shall be $\$ 75,000$ paid to the host institution. In addition, a grant of $\$ 5,000$ per year shall be made for support of research supplies, travel, and other legitimate academic expenses of the scholar. The application consists of three components:

1. The candidate must submit a proposal for the research to be undertaken and a statement of career plans and how the research activity will relate to the candidate's academic career.

2. The director of the laboratory in the institution at which the research will be performed shall submit an endorsement of the proposal and indicate the facilities and degree of support available for the candidate's research.

3. The chairman of the candidate's department shall submit his or her endorsement of the proposal and indicate the willingness of the institution to provide an academic appointment for the candidate upon completion of the scholarship.

The application and its components must be submitted online at www.aats.org by July 1. Announcement of the award will be made by the president of the American Association for Thoracic Surgery by December 15. The scholarship will begin July 1, 2007. Following completion of the two-year program, the scholar shall submit a written report of his/her research activities to the membership of the Association.

\section{The Western Thoracic Surgical Association Announcement of 2006 Annual Meeting}

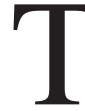
The Thirty-second Annual Meeting of the Western Thoracic Surgical Association will be held June 21-24 at the Sun Valley Resort in Sun Valley, Idaho. The scientific sessions are open to all duly qualified physicians. Participation in other Association activities for members, invited guests, and program participants requires payment of a social registration fee.

\section{Requests for Meeting Information}

Meeting preregistration and hotel registration forms will be available after January 2006 from:

Western Thoracic Surgical Association

900 Cummings Center

Suite 221-U

Beverly, MA 01915

978-927-8330; fax: 978-524-8890

wtsa@prri.com

\section{Material for the Program}

Scientific papers will be considered from members and nonmembers. Member sponsorship is not necessary.

Abstract submission is now closed. The 2006 program will be announced in mid-February.

Successful essayists must send the complete manuscript directly to The Journal of Thoracic and Cardiovascular Surgery and must not exceed 3000 words without illustrations. Electronic submissions are to be sent to http://jtcvs.editorialmanager.com where complete in- 
structions are also available. The essay length must be reduced appropriately when figures or tables are included.

\section{Application for Membership}

Applications for membership in the Association must be received by the Membership Committee Chairman no later than March 1 to be considered at the following annual meeting. Applicants must be sponsored by three members of the Association who are not members of the Membership Committee. Application forms will be issued only to sponsoring members.

Address correspondence to:

Chairman, Membership Committee

The Western Thoracic Surgical Association

900 Cummings Center

Suite 221-U

Beverly, MA 01915

978-927-8330; fax: 978-524-8890

wtsa@prri.com

\section{The American Board of Thoracic Surgery}

\section{Notices}

$\mathrm{T}$

he part I (written) examination will be held on December 4. It is planned that this examination will be given at multiple sites throughout the United States using an electronic format. The closing date for registration is August 1 each year. Those wishing to be considered for examination must apply online at www.abts.org.

To be admissible for the Part II (oral) examination, a candidate must have successfully completed the Part I (written) examination.

A candidate applying for admission to the certifying examination must fulfill all the requirements of the Board in force at the time the application is received. Please address all communications to the American Board of Thoracic Surgery, 633 North St Clair Street, Suite 2320, Chicago, IL 60611 (telephone: 312-202-5900).

\section{Requirements for Recertification/Maintenance of Certification}

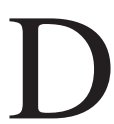
iplomates of the American Board of Thoracic Surgery who plan to participate in the Recertification/Maintenance of Certification process must hold an active medical license and must hold clinical privileges in thoracic surgery. In addition, a valid certificate is an absolute requirement for entrance into the recertification/maintenance of certification process. If your certificate has expired, the only pathway for renewal of a certificate is to take and pass the Part I (written) and the Part II (oral) certifying examinations.

The American Board of Thoracic Surgery will no longer publish the names of individuals who have not recertified in the American Board of Medical Specialties directories. The Diplomate's name will be published upon successful completion of the recertification/maintenance of certification process

The CME requirements include 70 Category I credits in either cardiothoracic surgery or general surgery earned during the 2 years prior to application. SESATS and SESAPS are the only self-instructional materials allowed for credit. Category II credits are not allowed. The Physicians Recognition Award for recertifying in general surgery is not allowed in fulfillment of the CME requirements. Interested individuals should refer to the Booklet of Information for a complete description of acceptable CME credits.

Diplomates should maintain a documented list of their major cases performed during the year prior to application for recertification. This practice review should consist of 1 year's consecutive major operative experiences. If more than 100 cases occur in 1 year, only 100 should be listed.

Candidates for recertification/maintenance of certification will be required to complete all sections of the SESATS selfassessment examination. It is not necessary for candidates to purchase SESATS individually because it will be sent to candidates after their application has been approved.

Diplomates may recertify the year their certificate expires, or if they wish to do so, they may recertify up to 2 years before it expires. However, the new certificate will be dated 10 years from the date of expiration of their original certificate or most recent recertification certificate. In other words, recertifying early does not alter the 10 -year validation.

Recertification/maintenance of certification is also open to Diplomates with an unlimited certificate and will in no way affect the validity of their original certificate.

The deadline for submission of applications for the recertification/maintenance of certification process is May 10 each year. A brochure outlining the rules and requirements for recertification/maintenance of certification in thoracic surgery is available upon request from the American Board of Thoracic Surgery, 633 North St Clair Street, Suite 2320, Chicago, IL 60611; telephone: 312-202-5900; fax: 312-202-5960; E-mail: info@abts.org. The booklet is also published on the Web site: www.abts.org. 